Ensayo

\title{
BEHAVIORAL ECOLOGY OF PHANAEUS DUNG BEETLES (COLEOPTERA: SCARABAEIDAE): REVIEW AND NEW OBSERVATIONS
}

\author{
Dana L. Price1 \& Michael L. MAY 2 \\ ${ }^{1}$ Graduate Program of Ecology and Evolution. 14 College Farm Road, DEENR \\ Rutgers University. New Brunswick, NJ 08904. Corresponding author: Department of Biological \\ Sciences, Salisbury University, 1101 Camden Avenue, Salisbury, MD 21801, U.S.A. \\ dlprice@salisbury.edu \\ 2Department of Entomology. 93 Lipman Drive, Blake Hall. Rutgers University. New Brunswick, NJ \\ 08901. May@aesop.rutgers.edu
}

Price, L. D \& May, L. M. 2009. Behavioral ecology of Phanaeus dung beetles (Coleoptera: Scarabaeidae): review and new observations. Acta Zool. Mex. (n. s.) 25(1): 211-238.

ABSTRACT. The genus Phanaeus Macleay comprises an important part of the Neotropical dung beetle fauna. With a few exceptions, these beetles are preferentially coprophagous, exploiting the moist excrement of large herbivores and omnivores. The nesting behavior (nidification) of Phanaeus is characterized mainly by tunneling rather than rolling behavior. Phanaeus species are Pattern II nesters: during the breeding season, the male and female cooperate in provisioning the nesting gallery, even though females can perform these activities alone. Their intricate behaviors and extravagant colors and horns have made these beetles the subject of numerous publications dealing with male-male competition, bisexual cooperation, nidification and more. This review is meant to give an overview of published and new behavioral observations for these species as well as to suggest directions for future research.

Keywords: Phanaeus, dung beetles, nidification, competition, bisexual cooperation, sexual selection

Price, L. D y May, L. M. Ecología comportamental de los escarabajos coprófagos Phanaeus (Coleoptera: Scarabaeidae): revisión y nuevas observaciones. Acta Zool. Mex. (n. s.) 25(1): 211-238.

RESUMEN. El género Phanaeus Macleay incluye una parte importante de la fauna neotropical de escarabajos del estiércol Con pocas excepciones, estos escarabajos son preferencialmente coprófagos, usando excrementos húmedos de grandes herbívoros y omnívoros. El comportamiento de nidificación de Phanaeus se caracteriza principalmente por la formación de galerías y más que rodaje, su comportamiento es de empujar. Las especies de Phanaeus pertenecen al Patrón II de nidificación: durante la temporada de reproduccion, los machos y hembras cooperan en el aprovisionamiento la galería del nido, aún cuando las hembras pueden realizer solas dicha actividad. $\mathrm{Su}$ elaborado comportamiento, colores y cuernos extravagantes hacen que estos escarabajos sean sujetos de numerosas publicaciones sobre la competencia entre machos, cooperación bisexual, nidificación, entre otras. Esta revisión tiene como objectivo el proporcionar informacion general sobre el comportamiento de estas especies asi como sugerir lineaminetos para futuras investigaciones.

Palabras clave: Phanaeus, escarabajos del estiércol, nidificación, competencia, cooperación bisexual, selección sexual. 
Phanaeus Macleay is a group of large (up to $25 \mathrm{~mm}$ in length) metallic dung beetles that have interested ecologists, taxonomists and collectors for well over a century. The 51 species of Phanaeus range from northern Argentina to the United States. Ecology, behavior and natural history of Phanaeus have been discussed by Halffter \& Matthews (1966), Halffter \& Edmonds (1982), Hanski \& Cambefort (1991), and Edmonds (1994). Here we provide an overview of foraging, mating, and nidification behavior of these beetles with an emphasis on adaptive traits that influence reproductive success and to suggest how some of these traits may have evolved. We also indicate where additional work is needed to understand the reported behaviors.

As Trivers $(1972,1976)$ emphasized, females that invest more heavily in offspring are expected to choose males that also make an increased investment. Phanaeus females apparently confirm this expectation. Scarabaeines in general show a strong tendency to form close temporary associations between one male and one female (pair bond), lasting from first encounter to completion of nidification during the reproductive season (Halffter \& Matthews 1966). Bisexual cooperation among Phanaeus includes joint excavation and provisioning of feeding galleries long before the female is sexually mature and ready to reproduce (Figure 1; $P$. daphnis Harold). Courtship and copulation are brief and simple while postcopulatory behavior is often an elaborate cooperative effort invested in nidification (Halffter \& Edmonds 1982).

With this in mind, we highlight the close relationship between feeding and reproduction, and hence sexual selection, in Phanaeus, based on the following: 1) Primary food sources (usually fresh dung) are not defendable due to intense competition. 2) Adults of both sexes (especially females) must feed to complete sexual development. 3) Food for adult feeding and, especially, for larval development, must be protected from excessive drying and from usurpation by other organisms and thus is sequestered in a burrow; the burrow also protects larvae and adults from parasitoids and predators. 4) Adults are long-lived and females exhibit low fecundity and are iteroparous. 5) Females will mate more than once. 6) Males thus benefit if they can maintain exclusive access to a mate until she completes oviposition of a clutch. 7) Males sometimes engage in intense scramble competition for females outside a burrow. 8) Males benefit by associating with females at the burrow because only there can males successfully defend females from potential rivals by fighting. 9) Once the association of male and female is established, selection favors males that assist in provisioning burrows because they enhance production of offspring by their mate. 10) Males probably also gain fitness through female choice of males willing to provision, as suggested by apparent female adaptations to attract and elicit provisioning by males. 


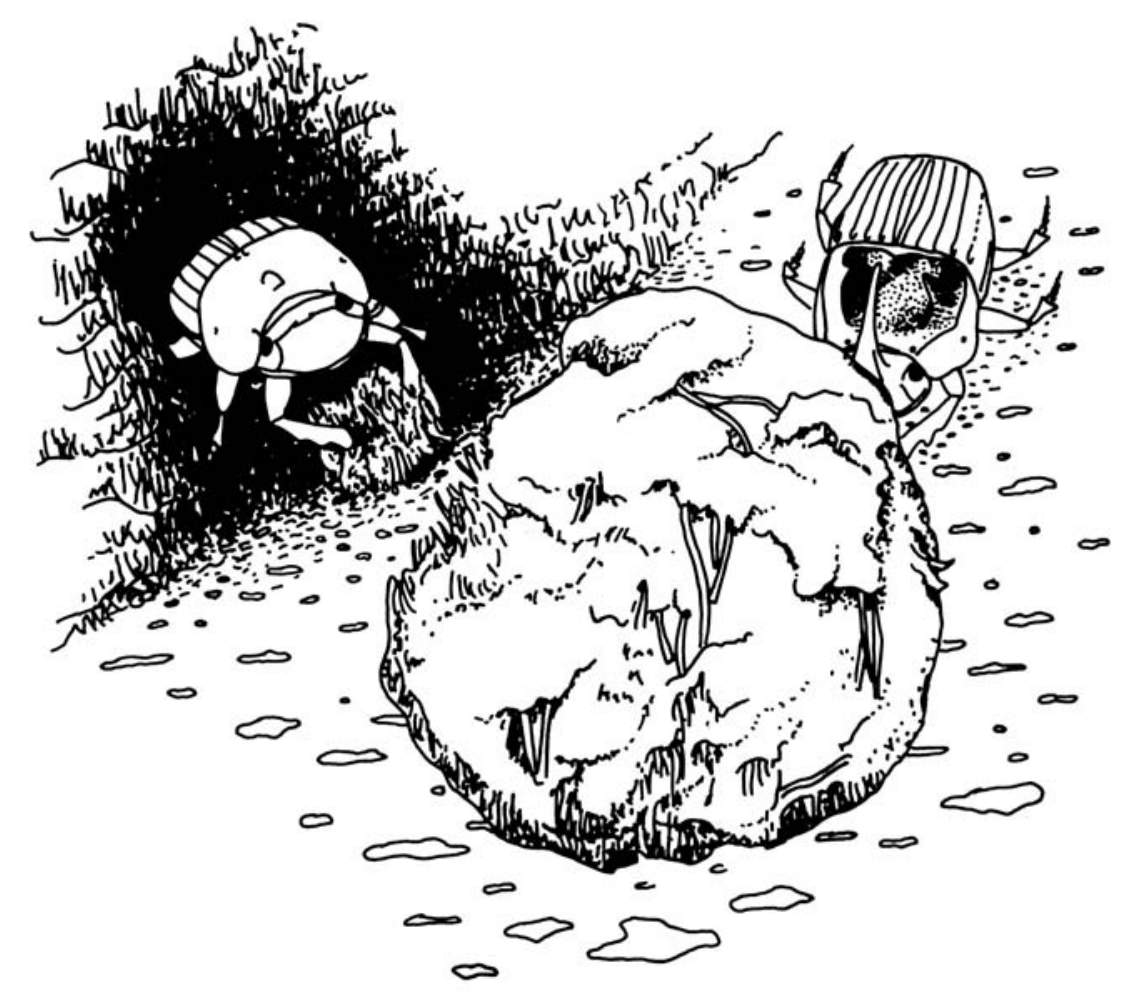

Figure 1. Phanaeus daphnis Harold. Cooperation between male and female. Male separates a small amount of dung that the female introduces in the burrow. (Picture redrawn from Halffter et al. 1974).

Food preference and detection. Dung beetles, including Phanaeus, generally feed as adults on the same food they provide for their larvae, and because male and female adults commonly share the same resource, feeding and reproductive behavior are not fully separable. Although our initial focus is on adult feeding, the early phases of both processes are generally identical and often simultaneous. Adaptive modifications for coprophagy among the Scarabaeinae have been examined by Halffter \& Matthews (1966).

Most Phanaeus species exploit moist excrement of large herbivores (e.g., cattle, tapirs), omnivores (e.g., humans, monkeys, swine), and certain carnivores (Edmonds 1994). The range of acceptable food, however, can be very broad. Among exceptions to the usual preference for dung are P. bispinus Bates and P. meleagris Blanchard, which are principally necrophagous (Halffter \& Matthews 1966), and P. halffterorum Edmonds, which may be exclusively mycetophagous (Hinton 1935, Halffter \& Matthews 1966, Edmonds 1979), though this species may also be attracted to carrion (Edmonds 1994). 
Edmonds (1994) collected several specimens of P. flohri Nevinson in areas covered by large rocks where exposed soil is restricted to cracks and crevices populated by scrubby vegetation. This habitat is attractive to burrowing animals, indicating that $P$. flohri may be an inquiline in mammal nests. Although Edmonds collected P. flohri on feces and carrion of unknown sources, Navarrete-Heredia \& Quiroz-Rocha (2000) collected this species in carrion traps of crawfish, canned tuna, and octopus. Further information on attraction of Phanaeus species to excrement, carrion, and/or fruit and fungi is noted in Appendix A. A partial bibliography of authors who reported food attraction is shown in Appendix B.

Food preferences of $P$. vindex Macleay and $P$. igneus Macleay have been investigated extensively. Stewart (1967) found that both species were more strongly attracted to feces of omnivores than to those of herbivores. Both preferred swine feces but also were attracted to opossum, dog, cow, raccoon, and horse dung. Fincher et al. (1970) also found that $P$. vindex and $P$. igneus were most strongly attracted to the feces of omnivores, such as swine, human, opossum, and rat. Feces of herbivores (cow, horse, rabbit, and sheep) were slightly more attractive than those from carnivores (fox, raccoon, and dog).

Despite their compact, heavy bodies, Phanaeus species fly well and rapidly, with remarkable control. When searching for food, most dung beetles fly close to the ground with little turning until food is encountered (Halffter \& Matthews 1966). Cruising species can be loosely divided into fast and slow fliers. Fast fliers, including Phanaeini, maximize their food search area (Hanski \& Cambefort 1991) but may overlook small or hidden resources. Some other dung beetles detect food odors by perching on vegetation (Hanski \& Cambefort 1991, Vulinec 2002), but no phanaeines are known to do so.

Once food is detected, beetles switch to a zig-zag pattern of close range search, sometimes bypassing food, then circling downwind and returning. When close to feces, the beetles land abruptly, probably in response to threshold odor intensity (Halffter \& Matthews 1966, Stewart 1967). Fincher (1972), e.g., observed that adult $P$. vindex Macleay rarely alighted directly on the feces but rather about a meter away, and then approached by walking, with head raised and antennal lamellae spread. Similar behavior has been reported in several species (P. mexicanus Harold, $P$. nimrod Harold, P. quadridens (Say), $P$. demon Laporte-Castelnau, $P$. difformis LeConte; Halffter \& Matthews 1966, Blume \& Aga 1976). As in many insects, the antennae are probably the principal chemoreceptive organs over longer distances and the maxillary palpi at very close range (Halffter \& Matthews 1966).

Because dung is often scarce and widely dispersed, selection undoubtedly favors rapid detection and exploitation. The advantages of early arrival at food sources may promote the use of indirect cues for food location in the Amazon rainforest of northeastern Peru, where competition for dung may be especially intense; e.g., 
Vulinec \& Quintero (cited in Herrera et al. 2002) observed Phanaeus in this region following a monkey troop.

Most Oxysternon and Phanaeus are generalist dung feeders with flight periods lasting many hours. Vulinec et al. (2003), however, reported a flight period for $P$. alvarengai of no more than 10 minutes early in the morning, substantially shorter than Coprophanaeus lancifer (Linnaeus), P. chalcomelas (Perty), P. cambeforti Arnaud, or Oxysternon conspicillatum Weber, which often attempted to fly for 30 min to several hours. Observations of $P$. yecoraensis Edmonds also suggest a short flight period, as these beetles arrived at bait traps only for a brief period just after dawn (Streit, pers. obs. 2004).

Sympatric species and interspecific competition. Life cycles of most Phanaeus are closely coordinated with a distinct dry season, followed by rains during warmer portions of the year. Species inhabiting regions that are continually warm and wet are active year-round (Edmonds 1994). Most tropical species are stenotopic with distributions determined by ground cover and prevailing climate (humidity, soil type, drainage, exposure to rainfall, etc.). Temperate species are much more eurytopic, inhabiting broad areas including several different ecological habitats (Edmonds 1994).

Dung beetle communities of subtropical North America, and Central and South America, include many sympatric species with similar food preferences, diel activity, and burrowing method. This is very conspicuous in Phanaeini, in which two species of different sizes commonly are present in the same locality. Relative abundances of coexisting pairs of Phanaeus species are related to differences in body size: if two species are similar in size, one of them is rare, probably due to interspecific competition (Hanski \& Cambefort 1991). Table 1 lists sympatric species of Phanaeus, and their reported relative abundance.

Activity periods usually differ in sympatric species pairs. In Georgia, flight activity of Phanaeus igneus Macleay peaked in late morning and early evening. In $P$. vindex Macleay, on the other hand, activity peaked in early afternoon, with a minor evening peak. However, as the number of daylight hours decreased, the flight activity of $P$. igneus shifted to coincide with that of $P$. vindex (Fincher et al. 1971). Similarly, $P$. cambeforti Arnaud and P. chalcomelas (Perty) in French Guiana had distinct activity maxima: $75 \%$ of $P$. cambeforti were captured between $6 \mathrm{~h} 00$ and $7 \mathrm{~h} 00$ and $70 \%$ of P. chalcomelas between $9 \mathrm{~h} 00$ and $13 \mathrm{~h} 00$ (Feer \& Pincebourbe 2005).

Habitat utilization may change slightly with increased competition (Blume \& Aga 1978). In eastern Texas, Phanaeus difformis LeConte and P. vindex Macleay both prefer, but are not restricted to, open grasslands on sandy soils. However, where the species co-occur locally, $P$. difformis replaces $P$. vindex on sandy soils and $P$. vindex tends to be restricted to clay soils (Blume \& Aga 1976, 1978). In the Florida panhandle, Edmonds (1994) found $P$. igneus and $P$. vindex syntopically, but $P$. igneus Macleay preferred sandy soils while $P$. vindex preferred soils with greater clay content. 
Table 1. Size, relative abundance and locality of co-occurring Phanaeus species. This table has been modified from Kohlmann (1991) Table 7.2. References: 1. Fincher 1975; 2. Fincher \& Woodruff 1979; 3. Fincher et al. 1969; 4. Fincher et al. 1971; 5. Dajoz 1994; 6. Morón \& Zaragoza 1979; 7.

Kohlmann, pers. obs., cited in Hanski \& Cambefort 1991; 8. Kohlmann, pers. obs., cited in Hanski \& Cambefort 1991; 9. Kohlmann \& Sanchez-Colon 1984; 10. Vulinec, pers. obs.; 11. Larsen, pers. obs. 12. Morón et al. 1985; 13. Avendaño-Mendoza et al. 2005; 14. Morón 1979; 15. Halffter et al. 1992; 16. Horgan 2005; 17. Fincher et al. 1986; 18. Spector \& Ayzama 2003; 19. Feer 2000.

\begin{tabular}{|c|c|c|c|}
\hline Species pair & Relative Abundance & Locality & Reference \\
\hline \multirow[t]{4}{*}{ P. igneus/ $P$. vindex } & $0.99 / 0.01$ & Blackbeard Island, Georgia, USA & (1) \\
\hline & $0.99 / 0.01$ & Cumberland Island, Georgia, USA & (2) \\
\hline & $0.13 / 0.87$ & Tifton, Georgia, USA & (3) \\
\hline & $0.03 / 0.97$ & Tifton, Georgia, USA & (4) \\
\hline P. quadridens/ P. vindex & $0.79 / 0.21$ & Arizona, USA & (5) \\
\hline \multirow[t]{2}{*}{ P. quadridens/ P. palliatus } & $0.97 / 0.03$ & Villa de Allande, Mexico & (6) \\
\hline & $0.08 / 0.92$ & Santa Cruz Acatlan, Mexico & (7) \\
\hline P. demon/P. daphnis & & Santa Cruz Acatlan, Mexico & (7) \\
\hline P. w. pilatei/ P. tridens & & Santa Cruz Acatlan, Mexico & (7) \\
\hline P. amithaon/P. furiosus & $0.32 / 0.68$ & Ajijic, Jalisco, Mexico & (8) \\
\hline P. quadridens/ P. adonis & & Ajijic, Jalisco, Mexico & (8) \\
\hline P. daphnis/P. mexicanus & $0.76 / 0.24$ & Teloloapan, Mexico & (9) \\
\hline \multirow[t]{2}{*}{ P. chalcomelas/ P. cambeforti } & Common/rare & Rondonia (Western Amazon), Brazil & (10) \\
\hline & $0.04 / 0.96$ & Cocha Cashu Biological Station, Peru & (11) \\
\hline P. meleagris/ P. lecourti & $0.89 / 0.11$ & Megantoni, Peru & (11) \\
\hline \multirow[t]{3}{*}{ P. endymion/ P. sallei } & $0.98 / 0.02$ & Chiapas, Mexico & (12) \\
\hline & $0.13 / 0.87$ & Guatemala & (13) \\
\hline & & Los Tuxtlas, Veracruz & (14) \\
\hline P. tridens/ P. scutifer & & Laguna Verde, Veracruz & (15) \\
\hline P. chalcomelas/ P. meleagris & $0.98 / 0.02$ & Chanchamayo, Peru & (16) \\
\hline P. difformis/P. vindex & $0.79 / 0.21$ & Burleson Co., Texas & (17) \\
\hline P. chalcomelas/P. bispinus & $0.76 / 0.24$ & Santa Cruz Province, Bolivia & (18) \\
\hline P. chalcomelas/P. cambeforti/ & $0.89 / 0.09 / 0.02$ & Nourague, French Guiana & (19) \\
\hline
\end{tabular}

Along an elevation transect in Peru, Larsen (2006, pers. comm.) collected $P$. cambeforti Arnaud at $800 \mathrm{~m}$, and P. meleagris Blanchard and P. lecourti Arnaud at $1700 \mathrm{~m}$. Around Cocha Cashu Biological station in Peru, Larsen collected P. bispinus Bates $(\mathrm{n}=1)$ and $P$. chalcomelas (Perty) $(\mathrm{n}=5)$ in mature floodplain forest, $P$. chalcomelas $(\mathrm{n}=13)$ in secondary floodplain forest, and $P$. cambeforti $(\mathrm{n}=137)$ and $P$. chalcomelas $(\mathrm{n}=6)$ in terre firme forest. With this detailed study of habitat preference, we can see that $P$. chalcomelas is much more eurytopic, whereas $P$. cambefort $i$ clearly prefers terre firme forest. Such habitat differences may allow species to coexist and reproduce in sympatry. 
Food transportation/relocation. The subfamily Scarabaeinae comprises both rollers and tunnelers. Generally, the "active partner" (usually the male in Scarabaeini and Canthonini, the female in Gymnopleurini, Sisyphini, and Phanaeini) initiates construction of the brood ball (Halffter \& Matthews 1966). This activity, or the completed ball, may function as a sexual display for the other member of the pair. Most Phanaeini are clearly tunnelers, but sometimes individuals of some species of Phanaeus push or roll a piece of dung some distance from the dropping, initially lifting the edge of the excrement with the head, then using both head and forelegs to push it (Halffter et al. 1974). Such "butting" behavior was first described by Halffter $\&$ Matthews (1966) for P. vindex Macleay, P. daphnis Harold (mistakenly identified as $P$. nimrod, Halffter et al. 1974), P. mexicanus Harold, and P. quadridens (Say). Subsequent observations have added $P$. palliates Sturm, $P$. tridens LaporteCastelnau, P. pyrois Bates, P. howdeni Arnaud, and P. demon Laporte-Castelnau (Halffter et al. 1974, Halffter \& Lopez 1977, Halffter \& Edmonds 1982, Hanski \& Cambefort 1991, Montes de Oca \& Halffter 1995, Horgan \& Fuentes 2005). These authors suggest that head butting is an above-ground extension of the behavior used by beetles to move dung through their underground tunnels. Nonetheless, although they do not use the hind legs to push and do not always shape the dung, movements of female $P$. daphnis to form a ball from the edge of cow dung were remarkably similar to those of Canthon, a typical roller (Halffter \& Matthews 1966, Halffter et al. 1974). When completed, the ball, up to 1.5 times the size of the insect, was rolled away. Butting behavior might, therefore, have been a precursor of rolling in taxa in which the latter has evolved.

In $P$. daphnis Harold and P. mexicanus Harold, butting apparently is fairly common but in the field is performed almost entirely by females; in one instance only, two females were observed butting a large piece of horse dung. Beetles butted dung 0.8-18 $\mathrm{m}$ from initiation to burial (Halffter et al. 1974). It is not known how the burrow site was selected, or why the butting stopped, but variation in distance is an important factor in dispersing dung over a large area. Butting traversed an approximately straight line but was discontinuous, sometimes with prolonged motionless periods. Speed across open ground was $<50 \mathrm{~cm} / \mathrm{min}$, and rolled pieces were frequently abandoned on the surface. In the laboratory, however, $P$. mexicanus pairs worked cooperatively, forming fresh cow dung into a series of irregular balls, 3-4 cm dia. that were then pushed (Halffter et al. 1974). The male separated pieces of dung that the female reshaped, or that the male itself transformed into irregular balls, rotating them several times between his meso- and metathoracic legs. Over the course of several hours, the female pushed 10 balls in succession to the same spot in the terrarium, until the original dropping was completely disintegrated.

Halffter \& Matthews (1966) observed $P$. vindex Macleay in Florida push a piece of human excrement $1.5 \mathrm{~m}$ before starting to detach small pieces that were then rolled 
and finally held by the forelegs while the beetle backed into the burrow. An apparent attempt by another $P$. vindex to bring two successive dung fragments to the same burrow resulted in the beetle missing the entrance by $20 \mathrm{~cm}$ and consequently abandoning the burrow (Halffter \& Matthews 1966).

These observations suggest that overland transportation is in some respects as highly developed in Phanaeus as in the Scarabaeini (Halffter \& Matthews 1966). The quantity of food can be far larger in relation to the size of the beetles than in Scarabaeini (see Figure 2). Transport of the excrement diminishes aggregation and subsequent competition around the dung source (Halffter \& Matthews 1966, Halffter et al. 1974, Halffter \& Lopez 1977, Montes de Oca \& Halffter 1995). When feeding and nidification burrows are scattered over a large area, the negative effects of concentrating burrows of one species under one dropping are notably reduced. Otherwise individuals compete for available space among themselves and with Scarabaeini and Coprini. Halffter et al. (1974) suggest this may largely explain the joint abundance of $P$. daphnis Harold and $P$. mexicanus Harold in some locations. Rolling thus permits two very similar sympatric species to coexist with a rich fauna of other Scarabaeinae, and it reduces the time required to completely destroy the dropping. This in turn reduces accessibility of the manure to flies. Food transportation also allows Phanaeus to utilize dung located on unsuitable substrates, such as rocks. It may also be an effective defense against kleptoparasitic dung beetles (Hanski \& Cambefort 1991).

From a different perspective, butting may facilitate formation of bisexual pairs (Halffter \& Matthews 1966, Halffter et al. 1974, Halffter \& Lopez 1977, Halffter \& Edmonds 1982). Males of P. mexicanus Harold or P. daphnis Harold land near a female pushing dung and follow her for a few centimeters. Rarely, a male pushes a fragment or assists the female (Halffter et al. 1974). If the female is burying, a male that joins her first eats directly from the dung (Halffter \& Matthews 1966) but may then help the female bury the remainder.

In P. tridens Laporte-Castelnau, males participate in butting more often than in other species studied (Halffter \& Edmonds 1982). If population density is high several males may be attracted to the same female engaged in pushing. This leads to furious intrasexual combat, after which the victor accompanies the female if she is still nearby. Nevertheless, the frequency of butting behavior by $P$. tridens females was always much less than $50 \%$; most females burrowed immediately beneath a food source, and in many populations no pushing was observed (Halffter \& Edmonds 1982).

Male-female cooperation in nesting is characteristic of Phanaeus species but is not obligatory. Females often nest alone and construct a nest beneath or adjacent to the food source. In such cases, gallery excavation may function as a sexual attractant. The degree of cooperation is higher, however, when nesting is preceded by fragment pushing, which thus is important in attracting potential mates in certain species and 
environmental conditions (Halffter \& Edmonds 1982). The initial male response to the visual stimulus of a female pushing a dung fragment may be reinforced by chemical ones (i.e. pheromones) at some point of the process (Halffter \& Edmonds 1982).
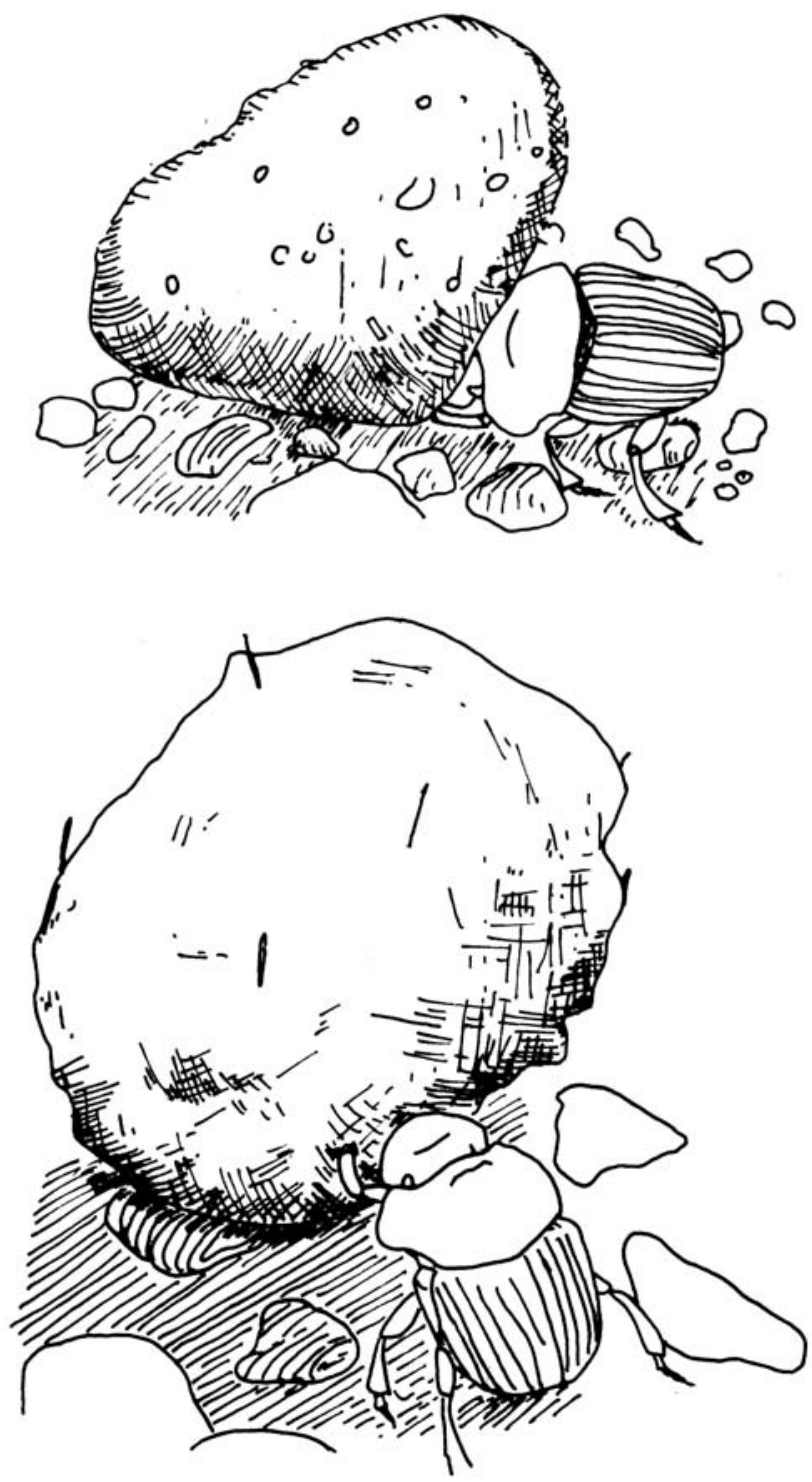

Figure 2. Top: Female Phanaeus mexicanus Harold rolling a piece of horse dung. Head is placed under edge of dung. Bottom: Beetle has lifted edge of piece with head and is pushing it over with forelegs. (Pictures from Halffter \& Matthews 1966). 
Burrowing behavior. Phanaeus vindex Macleay constructs two types of burrows, one for food storage and adult feeding, and the other for the brood ball (Fincher 1972). Similar behavior is characteristic of all species studied so far. When adults of either sex reach a dung mass, they immediately try to burrow in the soil beneath its edge, walking around the outer edge of the fecal mass, attempting to dig and apparently testing the soil with their heads and forelimbs when the soil is tightly compacted. If conditions were not satisfactory, they fly away. Newly attracted $P$. vindex immediately began constructing burrows with ease at the same site previously rejected by other individuals when the soil beneath the fecal pad was mechanically loosened.

In the field, beetles loosened the soil with powerful movements of the head and forelegs away from each other. The forelegs push the soil backwards so loose soil accumulates behind the beetle as it moves downward. Eventually the beetle turns and nudges the soil to the surface with the head. In loosely compacted topsoil, at least in the laboratory, the beetles do not push excavated soil to the surface but compress it along the edges of the burrow as they dig (Fincher 1972).

Feeding and feeding burrows. Reifungfrass, a term coined by Halffter \& Matthews (1966), refers to a lengthy period of feeding and maturation of adult Phanaeus following eclosion. This characteristic of many Scarabaeinae allows newly transformed adults to delay emergence on the surface to avoid harsh winter or hot, dry summer conditions (Halffter \& Edmonds 1982). Activity and feeding is closely coordinated with ovarian maturation, which can be divided into four phases: juvenile, previtellogenesis, vitellogenisis, and resorption. Each phase entails morphological and histological changes in the ovary and is coincident, in general, with certain norms of female behavior (Halffter \& Lopez 1977, Halffter \& Edmonds 1982). Juvenile through previtellogenesis periods are spent in the emergence burrow and most of vitellogenesis is spent in the feeding burrow.

In central Mexico, Phanaeus species may nest anytime between June and November. Adults eclosing during the dry season, from November to May, await rains in their natal burrow before digging to the surface. During this time they rely on adult tissues, including the ovary, to maintain metabolism. After the beetles become active, they eat voraciously during gonad maturation (20 - 40 days, depending upon the species) and vitellogenesis. Only then is the female ready for nesting and reproduction (Halffter \& Edmonds 1982).

Pre-reproductive feeding burrows may be constructed by either sex and are usually shallower than nidification burrows (Blume \& Aga 1976). The female, or both individuals if a male has joined her, detach with their forelegs small pieces of dung either from the original dropping or a rolled fragment. They carry or drag the fragments backwards into the burrow (Halffter \& Lopez 1972; Halffter et al. 1974). Once it is provisioned, the female and her associated male, if any, enter the burrow. 
Most time is spent within the gallery, which commonly is closed with a loose earthen plug pushed up from below (Halffter et al. 1974; Halffter \& Edmonds 1982). This protects both the beetles and the food store against predators, desiccation, invasion of flies, and intrusion of other beetles. When the entrance is open, either individual may position itself in the entrance, bracing its opened legs on the walls of the burrow. If movement or a passing shadow is detected, the beetle falls to the bottom of the burrow, clearly a predator avoidance response to small mammals and birds. Levey et al. (2004) reported that $P$. igneus Macleay made up $65 \%$ of the beetles consumed by burrowing owls in one site. Additional predators of Phanaeus species include other birds (Woodruff 1973), swine (Blume \& Aga 1978), and a staphylinid, Staphylinus maculosus, on P. vindex Macleay (Young 1998); Phanaeus are also frequent hosts to sphaerocerid flies (Sivinski 1983, Petersson \& Sivinski 1996).

Evidently the beetles leave the protection of their galleries only to seek food (Halffter \& Edmonds 1982). Under laboratory conditions (Halffter et al. 1974) pairs of Phanaeus provided with fresh food at their burrows did not vacate them for periods of two to three months. In the field, however, movement probably occurs every 2 to 3 days as provisions are exhausted or become inedible. Whether or not provisioning of the burrow is followed by preparation of a brood-ball depends on the condition of the ovarian follicle and not on the fact that a male and female are working together (Halffter et al. 1974).

Nidification. The critical phase of reproductive behavior in Scarabaeinae is nidification. Phanaeus have been categorized as Pattern II nesters (Halffter \& Matthews 1966; Halffter \& Edmonds 1982), i.e., nests contain one or more brood balls, each formed independently and residing in an isolated chamber. Larvae develop within the brood ball that, reinforced with larval feces, serves as the pupation site. This form of nesting is common among species with low fecundity.

Initiation of the first nesting gallery coincides with maturation of the first oocyte. Each ovary consists of four follicles that develop nearly simultaneously. Copulation takes place shortly before nesting begins (Halffter \& Lopez 1977). After copulation, spermatozoa are conserved in the spermatheca until the female is ready to oviposit. If copulation does not occur, egg development is arrested. Virgin females have never been observed to begin a nest (Halffter \& Edmonds 1982). Male-female cooperation appears to be very important to nidification, although mated females isolated from male contact are able to nest successfully.

The first detailed field observations of nidification were those of Lindquist (1935) on P. triangularis (Say) at cattle droppings. Burrows were branched, with the main tunnel $15-30 \mathrm{~cm}$ long $(2 \mathrm{~cm}$ in diameter) and the branch $7.5-20 \mathrm{~cm}$ long $(2.5 \mathrm{~cm}$ in diameter), was used for dung storage. Fall burrows of $P$. difformis LeConte and $P$. triangularis (Say) were slightly over $5 \mathrm{x}$ the depth of the burrows from earlier in the season, presumably to provide more protection during winter. In breeding boxes, the 
egg chamber was always deeper than feeding tunnels. Dung was taken into a cavity about $3-5 \mathrm{~cm}$ across and formed into a sphere. The surface of the ball was then evenly plastered with $.6 \mathrm{~cm}$ of soil except at one end, where it was applied more thickly, giving the ball a pyriform appearance. Soil coating reduces desiccation of the larval food. The egg was then laid in the thickened end of the ball, just under the surface in a small earthen cavity, not in contact with the manure as in a Copris ball, and when the egg hatched the larva dug into the interior and fed on the provision. After oviposition the beetle left to construct another brood ball and had no further interaction with the initial brood ball. Several days were required to dig a burrow and construct the egg housing (Lindquist 1935).

Construction of nidification burrows is similar in other species, with some variation in tunnel depth, thickness of the protective coating of soil, and number of brood balls (Table 2). In the field, nests normally contain no more than two brood balls, although pairs supplied continuously with excrement in the laboratory may prepare three balls using the same gallery and same dung store. A storage gallery is common among phanaeines, in nests prepared under the dung but rare in nests provisioned with rolled fragments (Halffter \& Edmonds 1982). Dung may be supplied either from a fresh deposit or stores within the nesting burrow or a nearby feeding burrow. In general, feeding burrows are not converted to nidification burrows, although $P$. daphnis Harold and P. mexicanus Harold may be exceptions (Halffter \& Lopez 1972). Burrow construction generally takes 2-5 days. Once completed, brood balls receive no further care, even when the pair remains in the nest. Breaches in the brood ball are repaired by the larva using its' own feces (Halffter \& Lopez 1972; Halffter \& Edmonds 1982).

Besides Phanaeus, several other Scarabaeinae (Bolbites, Oxysternon, some Dichotomius, and Heliocopris) enclose the egg and food mass in a clay shell in separate compartments (Halffter \& Matthews 1966). Ohaus (1913) reported the egg of $P$. floriger (= splendidulus Fabricius) as being in another cavity hollowed into the main food mass, with the space around the brood ball filled with earth except for an empty space at the tunnel end, which he called the antechamber. These observations have not been confirmed, however.

The clay shell protects the larva under dry or other adverse conditions. Also, the depth of the brood ball is dependent upon the amount of subsurface clay; the more clay content, the shallower the nest (Fincher 1972). Hence, brood balls are usually constructed in the first 10 to $15 \mathrm{~cm}$ of clay, probably because clay prevents excessive desiccation of larval food (Halffter \& Edmonds 1982). Soil texture affects frequency of nesting, larval survival and nest depth in $P$. vindex Macleay; the critical factor appears to be the higher rate of desiccation in progressively more sandy soils. Fincher (1973) reported larval survival rate of $95 \%$ in clay soil, $0 \%$ in sand; terraria with high clay content yielded more than twice as many brood balls as those with high sand content. 
Acta Zool. Mex. (n.s.) 25(1) (2009)

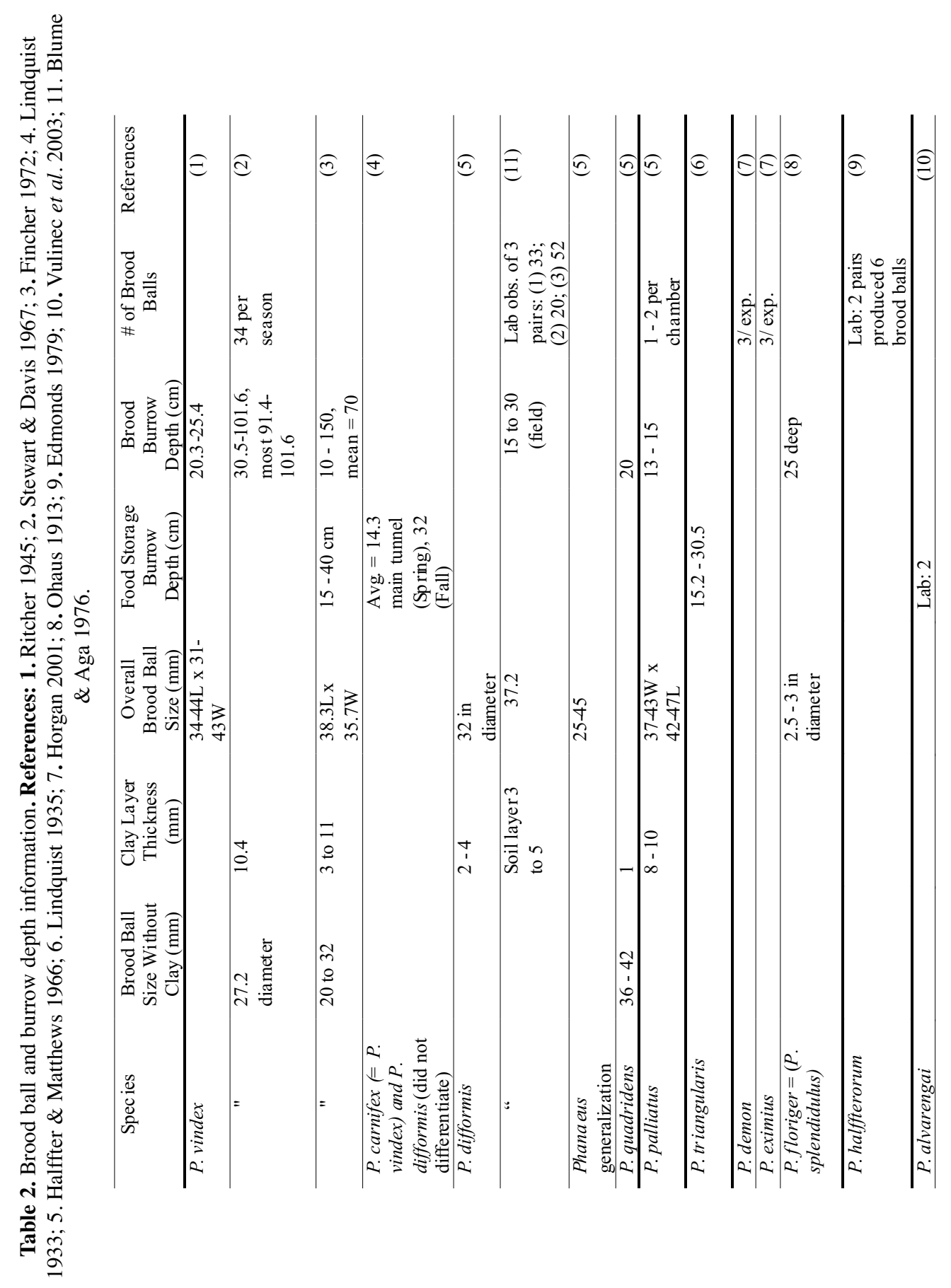


Adult $P$. halffterorum Edmonds, a mycetophagous species, treat partially decomposed mushrooms in the same manner as excrement or carrion by other Phanaeus; beginning with the stalk, the fungus was packed by pieces into the blind end of a tunnel dug directly beneath it. There it was either consumed by the adults or used to fashion brood balls similar to those of other species (Edmonds 1979, Halffter \& Edmonds 1982). Each nest contained two brood balls, each in a separate chamber.

Phanaeus daphnis Harold and P. mexicanus Harold, normally complete only three nesting cycles, after which (approximately 180 days following adult emergence) the germarium of the ovary is very reduced. In the laboratory, without a dry period that normally marks the end of reproductive activity in the field, 1-3 additional nesting periods may occur (Halffter \& Lopez 1972). Females may only lay 12 eggs in a season and perhaps even fewer when food is scarce. Horgan (2001) reported that pairs of $P$. demon Laporte-Castelnau and $P$. eximius Bates laid a maximum of three eggs and suggested that most females cannot lay all of their eggs at once. If dung collection is insufficient, as may occur in heavily colonized dung pads, no egg may be laid, particularly among large species such as $P$. demon, which requires over $50 \mathrm{~g}$ of fresh dung for each brood ball (Horgan 2001).

Halffter \& Edmonds (1982) never observed egg resorption in Phanaeus, even when females were kept alive long after they would have died in the field. TyndaleBiscoe \& Lopez-Guerrero (1982), however, induced resorption in the laboratory in $P$. daphnis Harold by crowding, which prevented burrow construction and oviposition. The germarium presumably continued to produce eggs that underwent some development in the vitellarium before resorption, as the maximum follicle size did not decrease with time. Most ovaries with a resorbing terminal oocyte maintained four follicles, although in a few, follicle number was reduced to two. In the field, these authors observed resorption in only 3 of 64 females. Two of these appeared to be resorbing only the terminal oocyte while the rest of the ovariole remained in breeding condition; the third apparently had ceased oocyte formation. The reason for resorption in the field is unknown, but it was not due to lack of fertilization. Phanaeus daphnis uses resources efficiently (Halffter \& Edmonds 1982), so females probably rarely encounter environmental stresses that induce oocyte resorption, although they clearly retain the ability to do so, and evidence in two of the three cases suggests that the process is reversible (Tyndale-Biscoe \& Lopez Guerrero 1982).

Intersexual cooperation. Cooperative efforts allow nesting pairs to dig further into the ground than lone females (Lindquist 1933). In $P$. carnifex (=P. vindex Macleay) and $P$. difformis LeConte average burrow length for one and two beetles was $12.3 \mathrm{~cm}$ and $18.0 \mathrm{~cm}$, respectively. Cooperative efforts also increase reproductive output. Paired females of $P$. daphnis Harold produced more than twice as many brood balls as females denied male company after copulation, and the number of larvae reaching third instar was greater in eggs laid by females in the 
company of males (Halffter \& Lopez 1977). It is not known, however, whether increased fecundity was due to reduced chance of sperm depletion or to male assistance in provisioning (Halffter \& Edmonds 1982).

Rasmussen's (1994) observations of $P$. difformis LeConte strongly support the conclusion that male provisioning assistance is important. Pair formation was typically initiated when a male entered a female's burrow. Initially the two beetles faced each other and each rapidly drummed and scratched with their forelegs on the head and forelegs of the other. During provisioning, females remained inside the burrow and pulled in dung fragments that males brought to the entrance, or both sexes searched for and retrieved dung. In the laboratory, cooperative provisioning usually occurred after copulation (20 of 24 cases) but in four cases, commenced immediately after pairing. The importance of male provisioning was indicated by female attempts to stimulate the behavior by drumming and scratching their partner if he was not provisioning or when he approached the burrow with dung. In response, males began or resumed searching for dung. Similar behavior occurs in both $P$. prasinus Harold and another phanaeine species, Coprophanaeus lancifer (Linnaeus) (Larsen, pers. comm. 2006).

Paired minor (hornless) and major (horned) males (see Alternative reproductive tactics below) were equally likely to provision a burrow in the field (Rasmussen 1994). Neither the rate of pellet delivery nor the total amount of dung provided differed between morphs. Assisting males, regardless of size, increased the provisioning rate and the total amount of dung stored and thus could influence both male and female reproductive success (Rasmussen 1994).

Intrasexual conflict. When $P$. difformis LeConte individuals of the same sex encounter each other at the entrance of or inside a burrow, a fight usually follows (Rasmussen 1994). In male-male contests combatants push each other with their pronota and attempt to position their horn underneath their opponent. A male that secures his horn under the other jerks it upward and attempts to flip his rival. One large-horned male also pinched opponents positioned on his back by pressing his horn backward. Contests inside the burrow were primarily pushing matches. Largerbodied males with larger horns usually won contests in both laboratory (69 vs. 2) and field (76 vs. 24) observations. If two competing males were equal in body size but differed in horn length, the male with the larger horn usually won. Contests in the laboratory, but not those in the field, between males of disparate body size or horn length were shorter than contests between males of similar size (Rasmussen 1994).

Females of $P$. difformis LeConte defend their nests from other females attempting to steal dung fragments or to take over the burrow (Rasmussen 1994). Female-female contests are similar in form to male-male contests except that females lack horns. Relatively large females were more likely to win contests ( 52 vs. $34 ; \mathrm{P}=0.05$ ), but the effect of body size was not as strong as among males. Female-female contests were rare 
in the laboratory and in the field were significantly shorter in duration than male-male contests. Rasmussen (1994) concluded that $P$. difformis LeConte females primarily defend dung used for food or nesting while males primarily guard the female against other males. Females will copulate with interloping males, and if one is larger and displaces her first nest mate, he will help the female. Success in aggressive interactions increases pairing success, particularly when male-male competition is intense.

Similar behaviors occur in both $P$. tridens Laporte-Castelnau (Halffter \& Edmonds 1982) and $P$. daphnis Harold (Halffter et al. 1974). In one case, a tridens female pushing a dung fragment was closely followed by three males, which fought violently among themselves, producing clearly audible scraping sounds. The winner of the two-minute battle pursued the female, drumming her elytra and pronotum with his front legs while helping intermittently to push the excrement. Soon afterwards, the pair buried the dung fragment.

Halffter \& Edmonds (1982) also reported two cases of female-female combat in P. tridens Laporte-Castelnau in which a female was forcibly ejected from the gallery occupied by another. A case of interspecific combat was also observed: a Copris lugubris Boheman male forcible ejected a female $P$. tridens from the entrance of a gallery being provisioned by a pair of $C$. lugubris, suggesting that interspecific competition for dung may occur even during nesting.

Alternative male tactics. Unlike some horned beetles that exhibit two discrete male morphs (Eberhard 1982, Cook 1987), in P. difformis LeConte male horns vary continuously with body size (Rasmussen 1994). Nevertheless, large-horned individuals are termed "major" males, while "minor" males possess shorter or no horns. In other dimorphic beetles minor males avoid male-male competition by either mating earlier in the activity cycle or adopting satellite mating tactics (Eberhard 1982, Siva-Jothy 1987, Goldsmith 1987). Similar behaviors have been recorded in $P$. difformis (Rasmussen 1994).

When male-male competition is intense, some small males act as "sneakers", remaining motionless near a pair's burrow or buried in loose sand surrounding the burrow (Rasmussen 1994). Sneaker males either enter the burrow when a paired male leaves to collect dung or they circumvent the burrow entrance while the resident male is stationed near the burrow entrance by digging a separate tunnel into the burrow. Over $90 \%(n=62)$ of sneaker males were smaller than the paired male. Furthermore, in the laboratory, smaller sneaker males remained in a pair's burrow longer than larger sneaker males, thus increasing their opportunity to mate with a paired female. The correlation between time spent sneaking and horn length was highly significant $(\mathrm{r}=-0.68, \mathrm{p}=0.003, \mathrm{n}=17)$.

In multiple mating studies, Rasmussen (1994) found that 16 of 24 females that had copulated within the last hour also copulated with a second introduced male. Four males were rejected and the remaining four did not attempt to mate. The size of 
the second male relative to the first male did not influence his copulation success and the average duration of second mating did not differ from first mating.

Male and female body size and male horn size do not significantly influence the ability of isolated pairs to associate, mate, or provision a burrow in $P$. difformis LeConte. However, because body and horn size do influence male and female competitive success, these attributes influence pairing success in competitive situations. The greater competitive success of larger-horned males in contests with opponents of equal body size and the greater success of smaller males, especially those with smaller horns, in sneaking suggest that male dimorphism in horn size and behavior may result from advantages in male-male competition for access to mates rather than from female choice (Rasmussen 1994).

Copulation. The copulatory sequence of Phanaeus daphnis Harold, P. mexicanus Harold (Halffter \& Lopez 1977), and P. difformis LeConte (Rasmussen 1994) may be characteristic of many dung beetles. Rasmussen (1994) noted in P. difformis that only copulations at the burrow entrance were observable in the field, while those in observation chambers always took place inside the burrow. Males pursuing a female usually make several copulation attempts, each lasting 45-120 s, before succeeding (Halffter \& Edmonds 1982); one P. daphnis male made 17 attempts to detain a female in 80 minutes. If successful, the male mounts the female and with his front legs drums rapidly and continuously on her pronotum and anterior part of the elytra, presumably as a tactile stimulus. He also extrudes his aedeagus in readiness for the moment the female ceases movement and he can engage her. Halffter \& Lopez (1977) suggest that the shape and smooth surface of the female may seriously impede mounting. On several occasions males successfully detained females, only to slip, fall and have to start over again.

To permit intromission the female raises her abdomen and separates the pygidium from the abdominal sternum (Halffter \& Lopez 1977 give a detailed account of the function of vaginal musculature in copulation). The male uses his legs to help raise the pygidium and connect the aedeagus to the genital opening. Erection and insertion of the penis proceeds when the male extends his middle legs while the hind legs lift and clasp the female. Males drum the female throughout copulation, although more softly after intromission. Males occasionally fall on their back while copulating without losing contact and may remain upended until copulation is completed. The entire copulation sequence lasts 4 to $12 \min (\mathrm{N}=11)$, intromission about 3 minutes. After some apparently successful copulations, the male tries to copulate again but without success. If the female fails to respond positively, the male does not try again.

Copulation success and duration in P. difformis LeConte did not differ between large and small individuals of either sex (Rasmussen 1994). In the laboratory, $78 \%$ (38 of 49) of males that paired with a female copulated. Three successful copulations were preceded by multiple brief $(15 \mathrm{~s})$ couplings. After copulation, females drummed 
and pushed their mate toward the burrow entrance. Thirty-seven \% of the males who mated then assisted the female in burrow provisioning, while the other $63 \%$ remained inactive near the burrow entrance. Male morphs did not differ in this behavior. In the field, 3 of 11 males deserted their mate immediately after copulation (Rasmussen 1994).

In Phanaeus, and probably other burrowing Scarabaeinae, copulation occurs only after maturation of the first oocyte and in the presence of the first series of 4 (Halffter \& Lopez 1977, Halffter \& Edmonds 1982). These authors speculate that at this time the ovary releases a hormone that induces physiological readiness for copulation. Males may be attracted by a pheromone since the females display no precopulatory behavior. Possible pheromonal stimulation of courtship or copulatory readiness is suggested by Halffter \& Lopez's (1977) observations that during the first 75 days after emergence, terraria occupied by a single pair of $P$. daphnis Harold yielded an average of 3.8 brood balls while an average of 13.4 brood balls per pair were recovered from terraria occupied by 3-10 pairs of beetles. These findings are consistent with the supposition that terraria occupied by many pairs contain a higher concentration of pheromone than those with single pairs and that this stimulates the grouped pairs to greater sexual activity. In several species of non-scarabaeid beetles Englemann (1970) found that a small quantity of sex pheromone is produced by the female most of the time, but the corpora allata, stimulated by maturation of the first oocyte, produce a hormone that increases pheromone production, thereby intensifying male courtship.

Pluot-Sigwalt (1982) discovered that some Scarabaeinae possess a rich assortment of exocrine glands common to both sexes, but a number of abdominal glands exhibit striking sexual dimorphism in number, distribution, and morphology and may function in bisexual relationships. Dimorphic glands were found in both Phanaeus and Coprophanaeus and in all Scarabaeini examined. Moreover, each genus has a characteristic pattern of abdominal glands.

Directions for future research. The forgoing supports our contention that food collection and feeding are critically entwined with sexual selection in Phanaeus and, by analogy, in many other dung beetles. Reviewing the specific arguments offered in the Introduction, the suggestion that competition for dung is so intense that the food source is not defendable (point 1) is supported by observations of the many beetles often attracted to fresh dung, the rapidity of the disappearance of the resource, and the fact that individuals sometimes fail to acquire enough dung to form a brood ball. That adults must feed to become sexually competent; that they are long-lived and females are iteroparous with low fecundity; that females mate more than once; and that males compete for females (points 2, 4, 5, and 7) are confirmed by direct observation. Benefits to males of mate guarding, and thus burrow guarding, follows from observations of polyandry and the likelihood of sperm competition. Our 
suggestions concerning the function and necessity of burrows (point 3) merely recapitulates the usual arguments for the evolution of burrowing, although we do not know of any explicit studies of effects of desiccation and predation on larval and adult fitness in Phanaeus. Support for point 8 that males associate with females at burrows because only there are the latter defendable seems strong in view of the support already noted for points 1 and 7 and the observations that males do mate with and defend females exclusively at burrows and appear to be especially attracted to females provisioning burrows. The last two points, that males gain fitness by enhancing offspring production by mates with which they associate, and that females are more likely to mate with males willing to provision, are crucial for operation of sexual selection. These still might be questioned because there has been, to our knowledge, no effort to assess the relative fitness of males that do not assist with provisioning and/or do not defend females in burrows; provisioning and defense may well reduce opportunities for additional matings by males. Nevertheless, it seems clear that provisioning males benefit by increasing the production of offspring by females they assist, that females behave so as to stimulate assistance by males, and that males risk losing some reproductive benefits due to probable sperm competition by other males.

Additional research is needed to understand evolution of food preference, food transportation, and resource overlap of species living in sympatry. Few studies have been designed primarily to determine food preferences so usually only one or two types of dung and/or carrion were offered. Exhaustive catalogs of food preference of species living where habitats have not been severely altered by human encroachment could be very informative. For example, Vulinec \& Quintero (cited in Herrera et al. 2002) observed Phanaeus (species not stated) following a monkey troop, possibly a strategy for efficient location of a specialized food source. Evolution of such specialized search behavior, or of preferences for a narrow range of dung sources or for carrion and/or other food resources may represent responses to inter- and intraspecific competition. To support this, however, field and laboratory data on food preference, effects of diet on development, and dispersion and persistence of resources are required.

Head-butting has been reported in only 9 of 51 species of Phanaeus, but it may provide insight into the evolution of more specialized rolling behavior as seen in Scarabaeini. Young (1978) reported, in laboratory tests of necrophagous scarabaeines that ball-rolling species consistently outcompeted species that butt food overland ("butters") or bury food at or near the food source ("buriers"). Little is known about the possible effects of substrate and microtopography, e.g., presence of leaf litter, of dispersion and size of dung or carrion concentrations, and habitat effects (e.g., forest vs. pasture) on resource apparency and abundance of non-scarab competitors, however. Also unknown is whether butting behavior evolved as a mechanism to avoid competition and/or predators or as a sexual attractant advertising control of a 
valuable resource. Answering these questions will require much more extensive information about species' behavior and the ecological context in which it occurs, in addition to understanding the phylogenetic relations of those species.

Almost nothing is known about mechanisms of sexual encounter and recognition in Phanaeus. Halffter \& Matthews (1966) and Palestrini et al. (1998) suggest that one reason for aggregation among dung beetles at food resources is mate location. Recognition in a few ball-rolling species (Gymnopleurus, Sisyphus, Scarabaeus and Canthon), seems to be effected by cuticular pheromones (Halffter \& Matthews 1966; Ortiz-Dominguez et al. 2006), as in numerous other insects (e.g., Coyne et al. 1994, Markow 2002, Savarit \& Ferveur 2002, Del Campo et al. 2003). Evidence reviewed above suggests that a search for cuticular pheromones and abdominal gland secretions may present an exciting avenue for new discoveries.

Male-male combat in Phanaeus is evidently related to sexual behavior and gallery defense (Halffter \& Edmonds 1982). Combat is also frequent among Scarabaeini (ball rollers), especially during the reproductive period when most balls are destined to receive eggs. In Scarabaeini, the "prize" is the ball being rolled, which assures copulation after rolling is terminated (Halffter \& Edmonds 1982). Similarly, among Phanaeus, the prize for males is access to the female for copulation, but whether fighting increases during times of reproductive activity is unknown. Of special interest would be information on combat frequency during feeding associations in contrast to that during nidification.

Because below ground activities are rarely observed, it was believed until recently that females only mated once in their lifetime. Rasmussen's (1994) examination of $P$. difformis LeConte, however, provides evidence to the contrary. This, along with evidence of sexual selection and male-male competition among other groups of scarabs and Coleoptera (Goldsmith 1987, Siva-Jothy 1987, Zeh \& Zeh 1992, Emlen 1997, Moczek \& Emlen 2000) raises numerous new questions about intra- and intersexual relationships. Why, for example, do females mate so readily with sneaking males that do not help with nesting duties? Why do some males stay to guard and help the female, when others provide no assistance? What is the relative reproductive success of non-helping males? How are the relative frequencies of these behaviors related to habitat, resource availability, local population density, and morph frequency? Does male-male interaction play a role in female mate selection?

Such questions have begun to be explored in Onthophagus (Scarabaeinae), another genus with major and minor males. In O. binodis Thunberg minor males have larger testes, transfer larger ejaculates and have longer sperm than major males (Simmons et al. 1999). None of these differences, however, occurred in the similar species, O. taurus (Schreber). In O. taurus $57 \%$ of males were minors, vs. $31 \%$ of male $O$. binodis. Fifty-two \% of an $O$. taurus male's time was allocated to paternity assurance behaviors (Hunt \& Simmons 2002a), and this time investment reduced the 
male's ability to provide care. This reduction is costly, since male care in $O$. taurus results in an increased weight of dung provided in the brood masses produced by the pair (Hunt \& Simmons 2002b), just as in Phanaeus. Moreover, the proportion of copulations achieved, and thus horned males' paternity, declined as the number of sneaker males increased in the population, and horned males reduced their care in relation to their declining paternity.

Horn size distribution among $P$. vindex Macleay collected in Georgia was examined by Rowland et al. (2005); seventy-three \% of 108 individuals were major horned males. Information on ejaculate volume and sperm length is unavailable for minors vs. majors of any Phanaeus species, however. Although Rasmussen (1994) did not report on the frequency of major and minor males, her work showed that in $P$. difformis LeConte, both morphs assist females and are equally successful at copulating. Cook (1988), however, found that large males of $O$. binodis Thunberg provision, but small hornless males do not.

Studies of sexual selection and female choice among Phanaeus species should also clarify factors that affect bisexual cooperation and parental care. Pattern II nesters like Phanaeines fabricate brood balls but place each in a separate chamber and have no interaction with their progeny after oviposition, even when the adult stays in the nest. Pattern III nesters, such as Cephalodesmius, on the other hand, form numerous brood balls in a single large cavity along with the female, which stays to care for the brood (Halffter \& Edmonds 1982). Phanaeus and other pattern II nesters may nevertheless provide some additional and costly parental care, e.g. by coating brood balls with a clay shell and digging deeper nests for young that must survive the winter months. Moreover, females stimulate males to help with provisioning, which ultimately produces more, larger, and presumably more fit young. These behaviors suggest that Phanaeus and other pattern II nesters may represent one possible evolutionary precusor that could have lead to parental care.

Careful studies of effects on reproductive success of male dimorphism, male and female resource acquisition, and aspects of nidification and direct parental care can provide some answers about how past and current selection, including sexual selection, has molded or maintains observed patterns of reproduction and parental effort. Phanaeus and its relatives appear to offer a very favorable system for such studies.

ACKNOWLEDGMENTS. We would like to thank W. D. Edmonds, Kevina Vulinec, and Douglas Tallamy for their discussion and thoughtful review of this manuscript. We would also like to thank Barney Streit, Trond Larsen, and Kevina Vulinec for providing new information regarding Phanaeus behavior, and Cesar Rodriguez-Saona for his translation of the abstract. 
Price \& May. Behavioral ecology of Phanaeus

\section{LITERATURE CITED}

Avendaño-Mendoza, C., A. Móron-Ríos, E.B. Cano, \& J. León-Cortés. 2005. Dung beetle community (Coleoptera: Scarabaeidae: Scarabaeinae) in a tropical landscape at the Lachua Region, Guatemala. Biodiversity and Conservation 14: 801-822.

Blume, R.R., \& A. Aga. 1976. Phanaeus difformis LeConte (Coleoptera: Scarabaeidae): Clarification of published descriptions, notes on biology, and distribution in Texas. The Coleopterists Bulletin 30: 199-206.

Blume, R.R. \& A. Aga. 1978. Observations on ecological and phylogenetic relationships of Phanaeus difformis LeConte and Phanaeus vindex MacLeay (Coleoptera: Scarabaeidae) in North America. Southwestern Entomologist 3: 113-120.

Cook, D. 1987. Sexual selection in dung beetles. I. A multivariate study of the morphological variation in two species of Onthophagus (Scarabaeidae: Onthophagini). Australian Journal of Zoology 35: $123-132$.

Cook, D. 1988. Sexual selection in dung beetles II. Female fecundity as an estimate of male reproductive success in relation to horn size, and alternative reproductive strategies in Onthophagus binodis (Coleoptera: Scarabaeidae). Australian Journal of Zoology 36: 521-532.

Coyne, J.A., A.P. Crittenden, \& K. Mah. 1994. Genetics of a pheromonal difference contributing to reproductive isolation in Drosophila. Science 265: 1461-1464.

Dajoz, R. 1994. Les coléoptères coprophages du sud-est de l'Arizona (Etats-Unis). Composition spécifique, biogéographie et structure des peuplements. Annales de la Societe Entomologique de France 30: 159-167.

Del Campo, M.L., S. Via, \& M.C. Caillaud. 2003. Recognition of host-specific chemical stimulants in two sympatric host races of the pea aphid Acyrthosiphon pisum. Ecological Entomology 28: 397 404.

Eberhard, W.G. 1982. Beetle horn dimorphism: Making the best of a bad lot. American Naturalist 119: 420-426.

Edmonds, W.D. 1979. A new species of Phanaeus from Mexico (Coleoptera: Scarabaeidae). PanPacific Entomologist 55: 99-105.

Edmonds, W.D. 1994. Revision of Phanaeus MacLeay, A New World Genus of Scarabaeinae Dung Beetles (Coleoptera: Scarabaeidae, Scarabaeinae). Contributions in Science, Natural History Museum of Los Angeles County 443: 1-105.

Emlen, D.J. 1997. Alternative reproductive tactics and male-dimorphism in the horned beetle Onthophagus acuminatus (Coleoptera: Scarabaeidae). Evolution 50: 1219-1230.

Englemann, F. 1970. The physiology of insect reproduction. Pergamon Press, Oxford, pp. 307.

Feer, F. 2000. Dung and carrion beetles of the rain forest of French Guiana: Composition and structure of the guild. Annales de la Societe Entomologique de France 36: 29-43.

Feer, F., \& S. Pincebourde. 2005. Diel flight activity and ecological segregation within an assemblage of tropical forest dung and carrion beetles. Journal of Tropical Ecology 21: 21-30.

Fincher, G.T. 1972. Notes on the biology of Phanaeus vindex (Coleoptera: Scarabaeidae). Journal of the Georgia Entomological Society 7: 128-133.

Fincher, G.T. 1973. Nidification and reproduction of Phanaeus spp. in three textural classes of soil (Coleoptera: Scarabaeidae). The Coleopterists Bulletin 27: 33-37.

Fincher, G.T. 1975. Dung beetles of Blackbeard Island (Coleoptera: Scarabaeidae). The Coleopterists Bulletin 29: 319-320.

Fincher, G.T., R.R. Blume, J.S. Hunter III, \& K.R. Beerwinkle. 1986. Seasonal distribution and diel flight activity of dung-feeding scarabs in open and wooded pasture in east-central Texas. The Southwestern Entomologist Supplement. No. 10: 1-35. 
Fincher, G.T., R. Davis, \& T.B. Stewart. 1971. Flight activity of coprophagous beetles on a swine pasture. Annals of the Entomological Society of America 64: 855-860.

Fincher, G.T., T.B. Stewart, \& R. Davis. 1969. Beetle intermediate hosts for swine spirurids in southern Georgia. Journal of Parasitology 55: 355-358.

Fincher, G.T., T.B. Stewart, \& R. Davis. 1970. Attraction of coprophagous beetles to feces of various animals. Journal of Parasitology 56: 378-383.

Fincher, G.T., \& R.E. Woodruff. 1979. Dung beetles of Cumberland Island, Georgia (Coleoptera: Scarabaeidae). The Coleopterists Bulletin 33: 69-70.

Goldsmith, S.K. 1987. The mating system and alternative reproductive behaviors of Dendrobias mandibularis (Coleoptera: Cerambycidae). Behavioral Ecology and Sociobiology 20: 111-115.

Halffter, G., \& W.D. Edmonds. 1982. The nesting behavior of dung beetles an ecological and evolutive approach. Instituto de Ecología, México.

Halffter, G., M.E. Favila, \& V. Halffter. 1992. A comparative study of the structure of the scarab guild in Mexican tropical rain forests and derived ecosystems. Folia Entomológica Mexicana (84): 131-156.

Halffter, G., V. Halffter, \& I. López. 1974. Phanaeus behavior: Food transportation and bisexual cooperation. Environmental Entomology 3: 341-345.

Halffter, G., \& Y. López. 1972. Nidificación y compartamiento sexual en Phanaeus. Folia Entomológica Mexicana 23-24: 105-108.

Halffter, G., \& Y.G. López. 1977. Development of the ovary and mating behavior in Phanaeus. Annals of the Entomological Society of America 70: 203-213.

Halffter, G., \& E.G. Matthews. 1966. The natural history of dung beetles of the subfamily Scarabaeinae (Coleoptera: Scarabaeidae). Folia Entomológica Mexicana 12-14: 1-313.

Hanski, I., \& Y. Cambefort. 1991. Dung Beetle Ecology. Princeton University Press, Princeton.

Herrera, E.R.T., K. Vulinec, C. Knogge, \& E.W. Heymann. 2002. Sit and wait at the source of dung - an unusual startegy of dung beetles. Ecotropica 8: 87-88.

Hinton, H.E. 1935. Anotaciones acerca de las costumbres micetofágicas de las especies de Phanaeus. Anales del Instituto de Biología, México 6(2).

Horgan, F.G. 2001. Burial of bovine dung by coprophagous beetles (Coleoptera: Scarabaeidae) from horse and cow grazing sites in El Salvador. European Journal of Soil Biology 37: 103-111.

Horgan, F.G. 2005. Effects of deforestation on diversity, biomass and function of dung beetles on the eastern slopes of the Peruvian Andes. Forest Ecology and Management 216: 117-133.

Horgan, F.G., \& R.C. Fuentes. 2005. Asymmetrical competition between Neotropical dung beetles and its consequences for assemblage structure. Ecological Entomology 30: 182-193.

Hunt, J. \& L.W. Simmons. 2002a. Behavioural dynamics of biparental care in the dung beetle Onthophagus taurus. Animal Behaviour 64: 65-75.

Hunt, J. \& L.W. Simmons. 2002b. Confidence of paternity and paternal care: covariation revealed through the experimental manipulation of the mating system in the beetle Onthophagus taurus. Journal of Evolutionary Biology 15: 784-795.

Kohlmann, B. 1991. Dung beetles in Subtropical North America. In I. Hanski \& Y. Cambefort (Ed.), Dung Beetle Ecology, pp. 116-132. Princeton University Press, Princeton, New Jersey.

Kohlmann, B., \& S. Sanchez Colon. 1984. Structure of a Scarabaeinae community: A numerical-behavioral study (Coleoptera: Scarabaeidae). Acta Zoológica Mexicana 2: 1-2.

Levey, D.F., R.S. Duncan, \& C.F. Levins. 2004. Use of dung as a tool by burrowing owls. Nature 431: 39.

Lindquist, A.W. 1933. Amounts of dung buried and soil excavated by certain Coprini (Scarabaeidae). Kansas Entomological Society 6: 109-124.

Lindquist, A.W. 1935. Notes on the habits of certain coprophagous beetles and methods of rearing them. United States Department of Agriculture. Circular 351. 
Markow, T.A. 2002. Perspective: female remating, operational sex ratio, and the arena of sexual selection in Drosophila species. Evolution 56: 1725-1734.

Moczek, A.P. \& D.J. Emlen. 2000. Male horn dimorphism in the scarab beetle, Onthophagus taurus: do alternative reproductive tactics favour alternative phenotypes? Animal Behaviour 59: 459-466.

Montes de Octa, T.E., \& G. Halffter. 1995. Daily and seasonal activities of a guild of the coprophagous, burrowing beetle (Coleoptera Scarabaeidae Scarabaeinae) in tropical grassland. Tropical Zoology 8: 159-180.

Morón, M.A. 1979. Fauna del coleopteros lamelicornios de la estacion de biologia tropical, "Los Tuxtlas," Veracruz, UNAM. Mexico. Anales del Instituto de Biología Universidad Nacional Autónoma México 50: 375-345.

Morón, M.A., F.J. Villalobos, \& C. Deloya. 1985. Fauna de coleópteros lamelicornios de Boca del Chajul, Chiapas, México. Folia Entomológica Mexicana 66: 57-118.

Morón, M.A., \& S. Zaragoza. 1976. Coleópteros Melonthidae y Scarabaeidae de Villa de Allende, Estado de México. Anales del Instituto de Biología de la Universidad Nacional Autónoma. México 47: 83-118.

Navarette-Heredia, J.L., \& G.A. Quiroz-Rocha. 2000. Macro-Coleopteros necrofilos de San Jose de Los Laureles, Morelos, Mexico (Coleoptera: Scarabaeidae Y Silphidae). Folia Entomológica Mexicana 110: 1-13.

Ohaus, F. 1913. Biologie des Phanaeus floriger Kirby (Col.). Deutsche Entomologische Zeitschrift 6: 681-686.

Ortiz-Dominguez, M., Favila, M.R. Mendoza-Lopez, O. Garcia-Barradas, \& J.S. Cruz-Sanchez. 2006. Epicuticular compounds and sexual recognition in the ball-roller, Canthon cyanellus cyanellus. Entomologia Experimentalis et Applicata 119: 23-27.

Palestrini, C., E. Barbero, \& A. Rolando. 1998. Intra-and interspecific aggregation among dung beetles (Coleoptera: Scarabaeoidea) in an Alpine pasture. Journal of Zoology, London 245: 101-109.

Petersson, E. \& J. Sivinski. 1996. Attraction of a kleptoparasitic sphaerocerid fly (Norrbomia frigipennis) to dung beetles (Phanaeus spp. and Canthon sp.). Journal of Insect Behavior 9: 695-708.

Pluot-Sigwalt, D. 1982. Diversité et dimorphisme sexuel de glandes tégumentaries abdominalis chez les Coléoptères Scarabaeidae. Comptes rendus des Sciances de L'Academie des Sciences (Paris) 294: 945-948.

Rasmussen, J.L. 1994. The influence of horn and body size on the reproductive behavior of the horned rainbow scarab beetle Phanaeus difformis (Coleoptera: Scarabaeidae). Journal of Insect Behavior 7: 67-82.

Ritcher, P.O. 1945. Coprinae of eastern North America with descriptions of larvae and keys to generaand species (Coleoptera: Scarabaeidae). Kentucky Agricultural Experiment Station Bulletin 477: 1-23.

Rowland, J.M., C.R. Qualls, \& L. Beaudoin-Ollivier. 2005. Discrimination of alternative male phenotypes in Scapanes australis (Boisduval) (Coleoptera: Scarabaeidae: Dynastinae). Australian Journal of Entomology 44: 22-28.

Savarit, F., \& J.F. Ferveur. 2002. Genetic study of the production of sexually dimorphic cuticular hydrocarbons in relation with the sex-determination gene transformer in Drosophila melanogaster. Genetic Research 79: 23-40.

Simmons, L.W., J.L. Tomkins, \& J. Hunt. 1999. Sperm competition games played by dimorphic male beetles. Proceedings of the Royal Society of London. B. 266: 145-150.

Siva-Jothy, M.T. 1987. Mate securing tactics and the cost of fighting in the Japanese horned beetle, Allmyrina dichotoma L. (Scarabaeidae). Journal of Ethology 5: 165-172.

Stewart, T.B. 1967. Food preferences of coprophagous beetles with special reference to Phanaeus spp. Journal of the Georgia Entomological Society 2: 69-77. 
Stewart, T.B., \& R. Davis. 1967. Notes on mites associated with coprophagous beetles. Journal of the Georgia Entomological Society 2: 21-26.

Sivinski, J. 1983. The natural history of a phoretic spaerocerid Diptera fauna. Ecological Entomology 8: 419-426.

Spector, S., \& S. Ayzama. 2003 Rapid turnover and edge effects in dung beetle assemblages (Scarabaeidae) at a Bolivian Neotropical Forest-Savanna ecotone. Biotropica 35: 394-404.

Trivers, R.L. 1972. Parental investment and sexual selection. In Campbell (Ed.) Sexual selection and the descent of man, pp. 1871-1971. Aldine Publishing Co. Chicago. Pp. 136-179.

Trivers, R.L. 1976. Sexual selection and resource-accruing abilities in Anolis garmani. Evolution 30 : 253-269.

Tyndale-Biscoe, M. \& Y. Lopez-Guerrero. 1982. Egg resorption in Phanaeus daphnis Harold (Coleoptera: Scarabaeidae). Folia Entomológica Mexicana 52: 27-39.

Vulinec, K. 2002. Dung beetle communities and seed dispersal in primary forest and disturbed land in Amazonia. Biotropica 34: 297-309.

Vulinec, K., W.D. Edmonds, \& D.J. Mellow. 2003. Biological and taxonomic notes on a rare phanaeine dung beetle, Phanaeus alvarengai Arnaud (Coleoptera: Scarabaeidae). The Coleopterists Bulletin 57: 353-357.

Woodruff, R.E. 1973. The scarab beetles of Florida. Part I, the Laprosticti (subfamilies Scarabaeinae, Aphodiinae, Hybosorinae, Ochodaeinae, Geotrupinae, Acanthocerinae). Florida Department of Agriculture and Consumer Services.

Young, O.P. 1978. Resource partitioning in a neotropical necrophagous scarab guild. College Park, Md. University of Maryland. Dissertation.

Young, O.P. 1998. Observations of rove beetle (Coleoptera: Staphylinidae) predation on dung beetles (Scarabaeidae) in Panama. The Coleopterists Bulletin 52: 217-221.

Zeh, D.W. \& J.A. Zeh. 1992. Sexual selection and sexual dimorphism in the harlequin beetle Acrocinus longimanus. Biotropica 24: 86-96. 
Price \& May. Behavioral ecology of Phanaeus

Appendix A. Food attraction

\begin{tabular}{|c|c|c|c|c|c|c|c|c|c|c|c|c|c|c|c|c|c|c|}
\hline Species & 駡 & $\begin{array}{l}\frac{\vec{d}}{\overrightarrow{0}} \\
\frac{\bar{d}}{\Sigma}\end{array}$ & $\begin{array}{l}.0 \\
.0 \\
0 \\
0\end{array}$ & 莺 & 号 & ڤ̆ & 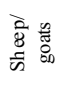 & 岸 & 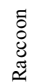 & $\begin{array}{l}\text { I } \\
\text { D. } \\
0 \\
0 \\
0\end{array}$ & 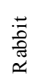 & 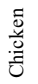 & $\stackrel{\infty}{0}$ & נ艹 & 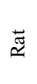 & $\begin{array}{l}\overrightarrow{50} \\
\overrightarrow{5} \\
\overrightarrow{5}\end{array}$ & . & 急 \\
\hline melibaeus & $\mathrm{x}$ & & & & & & & & & & & & & & & & & \\
\hline chalcomelas & $\mathrm{x}$ & $\mathrm{x}$ & $\mathrm{x}$ & & $\mathrm{x}$ & & & & & & & & & & & & & \\
\hline cambeforti & $\mathrm{x}$ & $\mathrm{x}$ & $\mathrm{x}$ & & & & & & & & & & & & & & & \\
\hline meleagris & & & & & $\mathrm{x}$ & & & & & & & & & & & & $\mathrm{x}$ & \\
\hline alvarengai & $\mathrm{x}$ & $\mathrm{x}$ & $\mathrm{x}$ & & & & & & & & & & & & & & & \\
\hline bispinus & $\mathrm{x}$ & & & & & & & & & & & & & & & & $\mathrm{x}$ & \\
\hline halffterorum & & & & & & & & & & & & & & & & $\mathrm{x}$ & $\mathrm{x}$ & \\
\hline endymion & $\mathrm{x}$ & $\mathrm{x}$ & $\mathrm{x}$ & $\mathrm{x}$ & & & & & & & & & & $\mathrm{x}$ & & $\mathrm{x}$ & $\mathrm{x}$ & $\mathrm{x}$ \\
\hline pyrois & $\mathrm{x}$ & $\mathrm{x}$ & & & & & & & & & & & & $\mathrm{x}$ & & & $x$ & $x$ \\
\hline hermes & $\mathrm{x}$ & & & & & & & & & & & & & & & & . & \\
\hline nimrod & & & & & & & & & & & & & & & & & $\mathrm{x}$ & \\
\hline tridens & $\mathrm{x}$ & & $\mathrm{x}$ & & & & & & & & & & & & & & $x$ & \\
\hline eximius & & & $\mathrm{x}$ & $\mathrm{x}$ & & & & & & & & & & & & & & \\
\hline daphnis & & & $\mathrm{x}$ & $x$ & & & & & & & & & & & & $\mathrm{x}$ & $x$ & \\
\hline adonis & $\mathrm{x}$ & & & & & & & & & & & & & & & & & \\
\hline triangularis & & & & & & & & & & & & & & & & & $x$ & \\
\hline flohri & & & & & & & & & & & & & & & & & $x$ & \\
\hline yecoraensis & $\mathrm{x}$ & & & & & & & & & & & & & & & & & \\
\hline demon & & & $\mathrm{x}$ & $\mathrm{x}$ & & & & & & & & & & & & & & \\
\hline scutifer & $\mathrm{x}$ & & & & & & & & & & & & & & & & & \\
\hline wagneri & & $\mathrm{x}$ & & $\mathrm{x}$ & & & & & & & & & & & & & & \\
\hline mexicanus & & & & $\mathrm{x}$ & & & & & & & & & & & & & & \\
\hline beltianus & $\mathrm{x}$ & $\mathrm{x}$ & & & & & $\mathrm{x}$ & & & & & & & & & & & \\
\hline howdeni & & $\mathrm{x}$ & & & & & & & & & & & & & & & & \\
\hline amethystinus & & & $\mathrm{x}$ & & & & & & & & & & & & & & & \\
\hline \multicolumn{19}{|l|}{ genieri } \\
\hline palliates & $x$ & & $\mathrm{x}$ & & & & $\mathrm{x}$ & & & & & & & & & & & \\
\hline quadridens & $x$ & & $\mathrm{x}$ & $\mathrm{x}$ & & & & & & & & & & & & & & \\
\hline igneus & $x$ & & $\mathrm{x}$ & $\mathrm{x}$ & $\mathrm{x}$ & $x$ & $\mathrm{x}$ & $\mathrm{x}$ & $\mathrm{x}$ & $\mathrm{x}$ & $\mathrm{x}$ & $x$ & $\mathrm{x}$ & & & & $x$ & \\
\hline difformis & $\mathrm{x}$ & & & & $\mathrm{x}$ & $\mathrm{x}$ & & & & & & & & & & & & \\
\hline vindex & $\mathrm{x}$ & & $\mathrm{x}$ & $\mathrm{x}$ & $\mathrm{x}$ & & $\mathrm{x}$ & $x$ & $\mathrm{x}$ & $\mathrm{x}$ & $\mathrm{x}$ & $\mathrm{x}$ & $\mathrm{x}$ & & $\mathrm{x}$ & & & $\mathrm{x}$ \\
\hline
\end{tabular}

Appendix B: Bibliography for food attraction.

Andressen, E. 2002. Dung beetles in a Central Amazonian rainforest and their ecological role as secondary seed dispersers. Ecological Entomology 27: 257-270.

Anduaga, S. 2004. Impact of the activity of dung beetles (Coleoptera: Scarabaeidae:

Scarabaeinae) inhabiting pasture land in Durango, Mexico. Environmental Entomology 33(5): 13061312.

Becton, E.M. 1930. The alimentary tract of Phanaeus vindex Macl. (Scarabaeidae). Ohio Journal of Science 30: 315-323.

Blume, R.R., \& A. Aga. 1976. Phanaeus difformis LeConte (Coleoptera: Scarabaeidae): Clarification of published descriptions, notes on biology, and distribution in Texas. The Coleopterists Bulletin 30: 199-206. 
Dajoz, R. 1994. Les Coleopteres Coprophages du sud-est de L'Arizona (Etats-Unis). Composition specifique, biogeographie et structure des peuplements. Annales de la Societe Entomologique de France 30(2): 159-167.

Deloya, C. 1996. Los Macro-Coleópteros necrófilos de Tepoztlán, Morelos, México (Scarabaeidae, Trogidae, Silphidae). Folia Entomológica Mexicana 97: 39-54.

Deloya, C., \& M.A. Morón. 1998. Scarabaeoidea (Insecta: Coleoptera) necrophagous de "Los Tuxtlas", Veracruz y Puerto Angel, Oaxaca. Dugesiana 5(2): 17-28

Edmonds, W.D. 1979. A new species of Phanaeus from Mexico (Coleoptera: Scarabaeidae). PanPacific Entomologist 55: 99-105.

Edmonds, W.D. 1994. Revision of Phanaeus MacLeay, A New World Genus of Scarabaeinae dung beetles (Coleoptera: Scarabaeidae, Scarabaeinae). Contributions in Science, Natural History Museum of Los Angeles County 443: 1-105.

Escobar, F. 2000. Diversidad de Coleopteros coprophagos (Scarabaeidae: Scarabaeinae) en un mosaic de habitats en la reserve natural Nukak, Guaviare, Colombia. Acta Zoológica Mexicana 79: 103121.

Essig, E.O. 1926. Insects of Western North America. The MacMillan Company, 12th Printing, 1952.

Estrada, A. \& R. Coates-Estrada. 1991. Howler monkeys (Alouatta palliata), dung beetles (Scarabaeidae) and seed dispersal: Ecological interactions in the tropical rainforest of Los Tuxtlas, Mexico. Journal of Tropical Ecology 7(4): 459-474.

Estrada, A., G. Halffter, R. Coates-Estrada, \& D.A. Meritt Jr. 1993. Dung beetles attracted to mammalian herbivore (Alouatta palliata) and omnivore (Nasua narica) dung in the tropical rain forest of Los Tuxtlas, Mexico. Journal of Tropical Ecology 9(1): 45-54.

Fincher, G.T. 1972. Notes on the biology of Phanaeus vindex (Coleoptera: Scarabaeidae). Journal of the Georgia Entomological Society 7: 128-133.

Fincher, G.T., T.B. Stewart, \& R. Davis. 1970. Attraction of coprophagous beetles to feces of various animals. Journal of Parasitology 56: 378-383.

Halffter, G., \& E.G. Matthews. 1966. The Natural History of Dung Beetles of the Subfamily Scarabaeinae (Coleoptera: Scarabaeidae). Folia Entomologica Mexicana 12-14: 1-313.

Halffter, G., M.E. Favila, \& V. Halffter. 1992. A comparative study of the structure of the scarab guild in Mexican tropical rain forests and derived ecosystems. Folia Entomológica Mexicana 84: 131-156.

Hanski, I., \& Y. Cambefort. 1991. Dung Beetle Ecology. Princeton University Press, Princeton.

Hinton, H.E. 1935. Anotaciones acerca de las costumbres micetofagicas de las especies de Phanaeus, Anales del Instituto de Biología, México 6(2).

Horgan, F.G. 2001. Burial of bovine dung by coprophagous beetles (Coleoptera: Scarabaeidae) from horse and cow grazing sites in El Salvador. European Journal of Soil Biology 37: 103-111.

Horgan, F.G. 2005. Effects of deforestation on diversity, biomass and function of dung beetles on the eastern slopes of the Peruvian Andes. Forest Ecology and Management 216: 117-133.

Howden, H.F., \& O.P. Young. 1981. Panamanian Scarabaeinae: Taxonomy, distribution, and habits (Coleoptera: Scarabaeidae). Contributions of the American Entomological Institute 18: 134-201.

Hunter, J.S. III \& J.L. Lancaster. 1984. Phanaeus difformis LeConte: (Coleoptera: Scarabaeidae): A new state record for Arkansas. The Coleopterists Bulletin 38(1): 56.

Janzen, D.H. 1983a. Costa Rica Natural History. The University of Chicago Press, Chicago and London. Janzen, D.H. 1983b. Seasonal change in abundance of large nocturnal dung beetles (Scarabaeidae) in Costa Rican deciduous forest and adjacent horse pasture. Oikos 41: 274-382.

Miller, A. 1954. Dung Beetles (Coleoptera, Scarabaeidae) and other insects in relation to human feces in a hookworm area of southern Georgia. American Journal of Tropical Medicine and Hygiene 3: 372-389. 
Miller, A. 1961. The mouthparts and digestive tract of adult dung beetles (Coleoptera: Scarabaeidae) with reference to the ingestion of helminth eggs. Journal of Parasitology 47: 735-744.

Morón, M.A. 1979. Fauna de coleópteros lamelicornios de la estación de biología Tropical "Los Tuxtlas”, Veracruz, UNAM, México. Anales del Instituto de Biología. UNAM, México 50: 375-454.

Morón, M.A. 1987. The necrophagous Scarabaeinae beetles (Coleoptera: Scarabaeidae) from a coffee plantation in Chiapas, Mexico: Habits and phenology. The Coleopterists Bulletin 41: 225-232.

Morón, M.A., F.J. Villalobos, \& C. Deloya. 1985. Fauna de coleopteros lamelicornios de Boca Del Chajul, Chiapas, México. Folia Entomologica Mexicana 66: 57-118.

Morón, M.A., A. Aragón, A.M. Tapia-Rojas, \& R. Rojas-García. 2000. Coleoptera Lamellicornia de la Sierra del Tentzo, Puebla, México. Acta Zoologica Mexicana 79: 77-102.

Navarette-Heredia, J.L. \& G. A. Quiroz-Rocha. 2000. Macro-coleopteros necrophilos de San Jose de Los Laureles, Morelos, Mexico (Coleoptera: Scarabaeidae y Silphidae). Folia Entomologia Mexicana 110: 1-13.

Ponce-Santizo, G., E. Andresen, E. Cano, \& A.D. Cuaron. 2006. Dispersion primaria de Semillas por Primates y dispersion secundaria por escarabajos coprofagos en Tikal, Guatemala. Biotropica 38(3): 390-397.

Price, D.L. 2004. Species diversity and seasonal abundance of scarabaeoid dung beetles (Coleoptera: Scarabaeidae, Geotrupidae, and Trogidae) attracted to cow dung in central New Jersey. Journal of the New York Entomological Society 112(4): 334-347.

Price, D.L. 2006. Notes on the scarabaeoid dung beetles (Coleoptera: Scarabaeidae, Geotrupidae, and Trogidae) of Hutcheson Memorial Forest, New Jersey, U.S.A. Entomological News 117: 347-350.

Rasmussen, J.L. 1994. The influence of horn and body size on the reproductive behavior of the horned rainbow scarab beetle Phanaeus difformis (Coleoptera: Scarabaeidae). Journal of Insect Behavior 7(1): 67-82.

Quiroz-Rocha, G.A. 1997. Phanaeus (Notiophanaeus) endymion Harold 1863 "Tortito" Coleoptera: Scarabaeidae. Dugesiana 4(1): 30-31.

Stewart, T.B. 1967. Food preferences of coprophagous beetles with special reference to Phanaeus spp. Journal of the Georgia Entomological Society 2: 69-77.

Stewart, T.B., \& K.M. Kent. 1963. Beetles serving as intermediate hosts of swine nematodes in southern Georgia. The Journal of Parasitology 49: 158-159.

Woodruff, R.E. 1973. The scarab beetles of Florida. Part I, the Laprosticti (subfamilies Scarabaeinae, Aphodiinae, Hybosorinae, Ochodaeinae, Geotrupinae, Acanthocerinae). Florida Department of Agriculture and Consumer Services.

Vulinec, K., W.D. Edmonds, \& D.J. Mellow. 2003. Biological and taxonomic notes on a rare phanaeine dung beetle, Phanaeus alvarengai Arnaud (Coleoptera: Scarabaeidae). The Coleopterists Bulletin 57: 353-357.

Recibido: 17 de septiembre de 2007

Aceptado: 20 de mayo de 2008 